\title{
Różnorodność paradygmatów dydaktyki akademickiej. O potrzebie komplementarności podejść
}

\section{KEYWORDS}

academic didactics, teaching paradigms, teaching strategies, teaching effects

\begin{abstract}
Sajdak-Burska Anna, Różnorodność paradygmatów dydaktyki akademickiej. O potrzebie komplementarności podejść [The plurality of academic didactics paradigms. On the need for complementarity of approaches]. Kultura - Społeczeństwo - Edukacja nr 2(14) 2018, Poznań 2018, pp. 25-38, Adam Mickiewicz University Press. ISSN 23000422. DOI 10.14746/kse.2018.14.2.
\end{abstract}

This paper concerns itself with the interdisciplinary nature of academic didactics as a field of social sciences that uses knowledge and results derived from educational sciences, psychology, philosophy, sociology and didactics specific to particular subjects. It was pointed out that considerations on teaching practices in all scientific disciplines constitute another source of knowledge for the field of academic didactics. The diversity of theoretical and methodological approaches is determined by science-specific and discipline-specific research methodology paradigms, diversified teaching cultures dependent on environmental conditions as well as diversified teaching class patters for students that are often specific to an educational profile. The issue addressed in this paper is whether a single didactic paradigm exists that would unify approaches so different in terms of theory and practice. The paper provides a map of academic didactics paradigms, a description of difficulties related to paradigmatic translations as well as the lack of consent to the multiparadigm approach and issues with interferences and shifts between paradigms. Despite the existing difficulties, the suggestion is made to promote the complementary attitude to various approaches. It is supported by the concept of relations between the assumed academic didactics effects and teaching strategies that lead thereto, which are constituted by different teaching and learning patterns. 


\section{Wprowadzenie}

Analiza rynku wydawniczego ostatnich dwóch dekad oraz lektura tekstów poświęconych dydaktyce akademickiej ujawnia ogromną różnorodność podejść teoretycznych i praktycznych w tej dziedzinie wiedzy. Dzieje się tak z pewnością dlatego, że refleksją nad procesem kształcenia w uczelni wyższej zajmują się nie tylko pedagodzy, w tym przede wszystkim specjaliści osadzeni subdyscyplinarnie w dydaktyce ogólnej i pedagogice szkoły wyższej, nie tylko dydaktycy przedmiotowi, zajmujący się dydaktyką szczegółową danej dyscypliny naukowej, ale także psycholodzy, filozofowie, politolodzy, ekonomiści, specjaliści od zarządzania, nowoczesnych technologii, dziennikarze, muzykoterapeuci... i wszyscy, którzy mają jakikolwiek kontakt ze studentami. Publikacje z zakresu dydaktyki akademickiej stanowią swoisty tygiel teoretycznych i praktycznych splątań. Promowanie tak zwanych dobrych praktyk bywa zawieszone w próżni teoretycznej, tak jak gdyby autor chciał nam powiedzieć: „to działa, choć nie wiem dlaczego”, czasem natomiast jest podbudowane niespójnymi hasłami, kategoriami wyprowadzonymi z różnych koncepcji teoretycznych. Niektóre pozycje wydawnicze odnoszące się wprost do dydaktyki szkoły wyższej mogą być nie tylko mocno kontrowersyjne, ale niekiedy wywoływać ostry sprzeciw. Tak wyłania się bardzo zróżnicowany obraz akademickiej refleksji nad kształceniem w murach uniwersytetów i szkołach wyższych. W naturalny sposób pojawia się pytanie: czy taka różnorodność (poza absolutnie błędnymi, dziwacznymi hybrydami teoretyczno-praktycznymi) jest pożądana i dobra, czy też powinniśmy wypracować jeden wzorzec i promować go jako związany z najnowszymi osiągnięciami z zakresu pedagogiki (dydaktyki) oraz psychologii kształcenia? To w istocie pytanie o to (a raczej seria pytań), czy dydaktyka akademicka jest nauką interdyscyplinarną oraz czy istnieje przyzwolenie na jej heterogeniczność i wieloparadygmatyczność (Kuhn, 2001; Krause, 2010), zróżnicowanie teoretyczne i praktyczne.

\section{O interdyscyplinarności dydakłyki akademickiej}

Pedagodzy, dostrzegając związki z dydaktyką ogólną oraz pedagogiką szkoły wyższej, w znakomitej większości odpowiedzą, że dydaktyka akademicka jest subdyscypliną pedagogiczną (Sajdak, 2016). Kanoniczne, pedagogiczne ujęcia dyscyplinarne opisują dydaktykę szkoły wyższej wręcz jako dział dydaktyki ogólnej, nabierający stopniowo cech samodzielnej subdyscypliny pedagogicznej. Zdaniem Wincentego Okonia (1993: 137) jej przedmiotem badań są cele i zadania, treści 
kształcenia i wychowania, metody, środki i formy organizacji procesu kształcenia w szkole wyższej, a także ustrój szkolnictwa wyższego oraz polityka oświatowo-naukowa. Podobnych źródeł dydaktyki akademickiej doszukuje się Teresa Bauman (2006: 170-171). Według niej dydaktyka szkoły wyższej w wyniku historycznego rozwoju stała się przekształconą wersją dydaktyki ogólnej, odnoszącą się do szkolnictwa na szczeblu wyższym, przedmiotem badań tej dyscypliny są zatem zagadnienia związane $\mathrm{z}$ funkcjonowaniem edukacji na szczeblu wyższym, czyli celami, zadaniami i funkcjami szkół wyższych, oraz z procesem akademickiego kształcenia, jego przebiegiem i ewaluacją. Na miejsce dydaktyki akademickiej pośród innych nauk pedagogicznych wskazuje także Stanisław Palka (2004: 31-36). Zdaniem tegoż autora dydaktyka szkoły wyższej ma najmocniejsze więzi z innymi subdyscyplinami pedagogicznymi - pedagogiką szkoły wyższej oraz dydaktyką ogólną. Więzi te wyznacza pole poznawcze subdyscypliny, bowiem przedmiotem badań dydaktyki akademickiej są procesy nauczania i wychowania intelektualnego. Autor pisze: „dydaktyka akademicka jest więc nauką o nauczaniu i wychowywaniu intelektualnym na uczelniach akademickich; jej uprawianie służy budowie teoretycznej wiedzy w powyższym zakresie oraz kształtowaniu podstaw praktycznej działalności na uczelniach akademickich” (Palka, 2004: 32). Pytając o autonomię dydaktyki akademickiej wśród innych współdziałających z nią nauk, takich jak filozofia, psychologia, socjologia, kulturoznawstwo, politologia, ekonomia, medycyna i inne, wskazuje na zależności, które mają charakter obustronnych inspiracji poznawczych i metodologicznych. Jeśli przyjmiemy, że dydaktyka akademicka jest tylko subdyscypliną pedagogiczną, to pojawią się zaraz bardziej kłopotliwe pytania. Jak bowiem zaklasyfikować obszary dydaktyki akademickiej, immanentnie związane bardziej z dyscyplinami macierzystymi, której praktyki dotyczą, niż z pedagogiką? Co zatem na przykład z dydaktyką medycyny, którą z powodzeniem uprawiają na całkiem dobrym poziomie osoby bez wykształcenia pedagogicznego? Czy dydaktyka medycyny nie wchodzi w zakres dydaktyki akademickiej? Ależ oczywiście, że wchodzi, a nawet stanowi mocny jej trzon. Można bowiem popatrzeć na dydaktykę akademicką nie tylko jako na teoretyczną dyscyplinę czy też subdyscyplinę naukową, ale także na praktykę kształcenia we wszystkich obszarach kształcenia. Przypomnijmy, iż na potrzeby wprowadzenia Krajowych Ram Kwalifikacji dla Szkolnictwa Wyższego wyróżniono osiem obszarów kształcenia: studiów humanistycznych, studiów społecznych, studiów w naukach ścisłych, studiów przyrodniczych, studiów technicznych, studiów medycznych, studiów rolniczych, leśnych, weterynaryjnych oraz studiów poświęconych sztuce. Każdy z nich może budować wiedzę teoretyczną dotyczącą procesu kształcenia studentów. Nie sposób nie docenić bowiem waloru refleksji uprawianej przez nauczycieli wszyst- 
kich obszarów kształcenia i poszczególnych dyscyplin nauki nad własną praktyką. Kształcenie studentów w poszczególnych obszarach studiów nie może być jednak $\mathrm{z}$ racji specyfiki studiów ujednolicone i jednoparadygmatyczne. Inaczej kształceni są studenci kierunków humanistycznych, inaczej kierunków matematycznych, inaczej przyrodniczych, a jeszcze inaczej kierunków poświęconych sztuce. Owo zróżnicowanie poszczególnych ścieżek dydaktycznych może wynikać z przynajmniej czterech powodów:

1) dominującego w danej dyscyplinie naukowej paradygmatu metodologicznego;

2) specyficznych dla poszczególnych kierunków kształcenia form i metod zajęć dydaktycznych;

3) kultury kształcenia w danym uniwersytecie, jednostce, katedrze;

4) specyfiki dydaktyki przedmiotowej danej dyscypliny (jeśli dyscyplina taką posiada).

Proces kształcenia studentów od czasów Wilhelma von Humboldta został nierozerwalnie powiązany z prowadzeniem przez nauczyciela akademickiego badań naukowych, u podstaw których leżała zawsze określona metodologia. Jedność nauki i kształcenia wyrażała się między innymi w powinnościach nauczyciela akademickiego jako tego, który, prowadząc proces badawczy, upowszechniał, głosił w trakcie wykładów w murach uniwersytetu wyniki swoich badań. Taki sposób patrzenia na dydaktykę akademicką widoczny jest także w pracach Sergiusza Hessena, który na początku XX wieku podkreślał, iż uniwersytet nie jest zakładem nauczania, lecz wyższą szkołą naukową, w której nauczyciel nie naucza swojego przedmiotu, lecz wypowiada publicznie swoje poglądy naukowe oraz prowadzi poprzez swoje badania naukowe nigdy niekończące się nauczanie (Hessen, 1997: 377). Nic więc dziwnego, że największy wpływ na kształt procesu kształcenia studentów miały aktualne teorie, koncepcje oraz stosowane w danej dyscyplinie nauki modele prowadzenia badań naukowych. Z tak wyznaczoną ścieżką spuścizny modelu uniwersytetu humboldtowskiego mamy dziś do czynienia. Jeśli w danej dyscyplinie nauki dominujący paradygmat metodologiczny opiera się na eksperymentach, pomiarach i pracy w laboratorium, to oczywiście ten właśnie sposób prowadzenia badań znajdzie swoje odzwierciedlenie zarówno w preferowanych formach pracy ze studentem, jak i w patrzeniu na człowieka i proces jego kształcenia przez pryzmat metodologii nauk przyrodniczych (można by rzec, iż metodologia nauk przyrodniczych odbija swoją matrycę na podejściu do procesów społecznych). Nikogo też nie dziwi, że inaczej kształci się na kierunkach, w których zarówno praca badawcza, jak i zajęcia ze studentami związane są z analizą tekstów i rozważaniem kontekstów kulturowych, umożliwiających dojście do oryginalnych 
interpretacji. Nie bez znaczenia jest też to, jaka jest tak zwana „kultura kształcenia” $\mathrm{w}$ danym uniwersytecie, na danym wydziale czy w katedrze. Tu z kolei działają mechanizmy socjalizacji, wrastania młodego nauczyciela akademickiego we wzorce promowane przez Mistrza i kierownika katedry (także we wzorce dydaktyczne) i odtwarzania ich jako związanych ze specyfiką kształcenia w danym środowisku. Sytuację różnorodności w dydaktyce akademickiej dodatkowo wzmacniają dydaktyki przedmiotowe (lub ich brak). Dydaktycy przedmiotowi, pracujący w uczelniach wyższych, zajmujący się kształceniem przyszłych nauczycieli w obszarze dydaktyki danego przedmiotu, często przenoszą wzory kształcenia preferowane w szkolnictwie niższego szczebla w obszar szkolnictwa wyższego. Będąc pod silnym wpływem matrycy metodologicznej danej dyscypliny naukowej, nierzadko nie dostrzegają złożoności różnych koncepcji kształcenia, nie podejmują dyskusji o kształcie dydaktyki w odmiennych paradygmatach (Suska-Wróbel, 2009: 198199). Biorąc pod uwagę powyższe argumenty, pytanie o to, czy można dydaktykę akademicką potraktować tylko jako (sub)dyscyplinę pedagogiczną, czy też jako naukę przekraczającą granice dyscyplinarne, ma głęboki sens. Moim zdaniem wyznaczanie ostrych granic dyscyplinarnych jest obarczone dużym ryzykiem. Wielu badaczy wskazuje zatem na konieczność płynnego do nich podejścia. Interdyscyplinarność wywołuje jednak także wiele niepewności i powoduje najczęściej utratę względnego poczucia bezpieczeństwa poruszania się po znanych polach. Współdziałanie badaczy wielu dyscyplin niesie z sobą ryzyko na przykład niemożności porozumienia się na poziomie używanego języka i stosowanych do interpretacji teorii, jest jednak szansą na życiodajne impulsy dla nowego, szerszego spojrzenia na przedmiot badań i w rezultacie rozwoju każdej z dyscyplin.

\section{Paradygmaty dydaktyczne w przestrzeni akademickiego kształcenia}

Jednoczesna pedagogiczność i interdyscyplinarność dydaktyki akademickiej jest niewątpliwie jej zaletą, ale też i sporym utrudnieniem w teoretycznym porządkowaniu opisywanych praktyk. W przestrzeni wielu dyskusji nad szkolnictwem wyższym oraz $\mathrm{w}$ wielu dokumentach na jego temat raz po raz podkreśla się konieczność zmiany paradygmatycznej w podejściu do kształcenia, którą to obrazuje przejście od modelu skoncentrowanego na treściach, standardach, osobie nauczyciela i dyrektywnym nauczaniu do modelu skoncentrowanego na osobie studenta, procesie jego studiowania i efektach kształcenia. Początków takich postulatów należy upatrywać w pracach George’a Browna, Madelaine 
Atkins (1988) oraz Roberta Barra i Johna Tagga (2000: 198-200). Zwłaszcza ci ostatni autorzy przyczynili się upowszechnienia przewrotu dydaktycznego znanego pod nazwą "the shift from teaching to learning" (zmiana od nauczania do uczenia się), opisującego przejście z paradygmatu nauczania kierowanego do paradygmatu uczenia się. W polskiej pedagogice pojawiło się również szereg prac, w których autorzy kreślą mapy paradygmatyczne odnoszące się wprost do dydaktyki. W obszarze kształcenia osób dorosłych Mieczysław Malewski (2010), nawiązując wprawdzie do prac Robina S. Ushera, wyróżnił cztery paradygmaty: pozytywistyczny, hermeneutyczny, krytyczny i postmodernistyczny, jednak w odniesieniu do refleksji nad edukacją dorosłych nakreślił trzy typy dydaktyk: technologiczną, humanistyczną i krytyczną. Moim zdaniem jednak bardziej użyteczna dla porządkowania teorii i praktyk kształcenia w uniwersytetach i szkołach wyższych jest mapa paradygmatów dydaktycznych proponowana przez Dorotę Klus-Stańską (2002; 2009; 2010). Autorka wprawdzie podkreśla, iż nie rości sobie prawa do budowania struktury dydaktyki, lecz próbuje uporządkować i ujawnić pewne stany rzeczy, rekonstruując paradygmaty na skrzyżowaniu dwóch kryteriów: teoretycznego (epistemologicznego i aksjologicznego) oraz pragmatycznego. Jej zdaniem we współczesnej polskiej dydaktyce można wyróżnić paradygmaty: funkcjonalistyczno-behawiorystyczny, humanistyczno-adaptacyjny, konstruktywistyczno-psychologiczny, konstruktywistyczno-społeczny oraz krytyczno-emancypacyjny. Twórczą adaptacją propozycji D. Klus-Stańskiej jest mapa paradygmatów kształcenia studentów i wspierania rozwoju nauczycieli akademickich przedstawiona w pracy Anny Sajdak (2013), która redukuje liczbę paradygmatów do czterech: behawiorystycznego, humanistycznego, konstruktywistycznego oraz krytyczno-emancypacyjnego. Każdy paradygmat wyznacza odmienna antropologia, epistemologia, aksjologia, psychologiczna teoria procesu uczenia się, które to w bezpośredni sposób przekładają się na pedagogiczne teorie nauczania-uczenia się, odmienne stanowienie celów kształcenia, określanie treści nauczania-uczenia się, metody kształcenia, rodzaje sprawowanej kontroli czy sposoby oceniania, wreszcie na odmienny typ relacji współdziałania nauczyciela i osoby uczącej się. Rekonstrukcja choćby głównych założeń poszczególnych paradygmatów czy dyskusji zogniskowanej wokół różnic $\mathrm{w}$ prezentowanych stanowiskach przekraczałaby znacząco ramy niniejszego artykułu. Jest zresztą zbędna, gdyż celem artykułu nie jest wskazanie konkretnego paradygmatu jako pożądanego czy dominującego, lecz teza o potrzebie komplementarności podejść w procesie kształcenia studentów, rozpatrywana nie z perspektywy danego paradygmatu czy dyscypliny naukowej, ale z perspektywy ogółu procesów akademickiego kształcenia. Zanim jednak zostaną podane argu- 
menty przemawiające za komplementarnością podejść, warto zwrócić uwagę na trudności, jakie mogą pojawić się w związku ze specyfiką funkcjonowania paradygmatów w obszarze nauk humanistycznych i społecznych. Pamiętać należy, iż u źródeł opisania struktury rewolucji naukowych przez Thomasa S. Kuhna leżały badania i obserwacje poczynione w obszarze nauk przyrodniczych, w których można było opisać zastępowanie jednej struktury przez nową na drodze rewolucji. Wkrótce po wprowadzeniu do obiegu naukowego kategorii paradygmatu sam autor zaczął się zastanawiać, czy jego spostrzeżenia są adekwatne dla nauk humanistycznych lub społecznych, gdzie różnorodne poglądy metodologiczne i style myślenia funkcjonują równolegle, nierzadko konkurując ze sobą. To może rodzić szereg trudności, do których należą przede wszystkim: zagrożenie fundamentalizmem, ostrą rywalizacją i niezgodą na wieloparadygmatyczność, trudności w przekładach paradygmatycznych oraz paradygmatyczne splątania, przesunięcia. Zjawiska te dają się stosunkowo łatwo zaobserwować w przestrzeni wielu publicznych dyskusji nad kształtem procesu kształcenia w szkole wyższej i jego jakością. W trakcie debat naukowych pojawiają się spory, u źródeł których leżą rozbieżności ocen, niezgoda sądów, nieprzystawalność opinii, wynikających wprost z przyjęcia przez poszczególnych autorów odmiennych podstaw teoretycznych czy metodologicznych. Dyskusje takie przynależą nauce i wręcz służą jej rozwojowi, czasem jednak pojawia się pewnego rodzaju wrogość, która doprowadza do zarzucenia podstaw racjonalnego dyskursu. Uczestnicząc w wielu spotkaniach różnych grup zaangażowanych w zapewnienie i podnoszenie jakości kształcenia w uniwersytecie, często jestem świadkiem właśnie takich sporów natury fundamentalistycznej. Obszary napięć wyznaczają odmienne odpowiedzi na przykładowe pytania:

- Czy edukacja na poziomie wyższym ma mieć charakter transmisyjny i selekcyjny, czy też może być przestrzenią poszukiwania przez młodych ludzi własnych ścieżek rozwojowych i profesjonalnych?

- Czy kształcenie ma przybierać postać realizacji z góry przewidzianych sztywnym programem studiów obowiązkowych laboratoriów, warsztatów, ćwiczeń, wykładów i praktyk, czy też program kształcenia może być na tyle elastyczny, by pozostawać w obszarze wolności i autonomii współdziałających w ramach tutoriali podmiotów?

- Czy lepiej stosować testy i zadbać o jak najbardziej obiektywny pomiar wiedzy i umiejętności studentów, czy też można powrócić do egzaminów ustnych i niepoddających się klasycznej standaryzacji prac pisemnych?

Fanatyczni zwolennicy jednego stanowiska, patrząc przez pryzmat własnej dyscypliny i obszaru kształcenia, nie tylko nie rozumieją stanowisk przeciwnych, ale 
często je także wręcz deprecjonują i odmawiają im prawa równoprawnego współistnienia. Spory dotyczą nie tylko przedstawicieli różnych obszarów nauk, ale też często toczone są „na własnym podwórku”. Bogusław Śliwerski trafnie spostrzega, iż

fundamentalizm w humanistyce, a w pedagogice w szczególności, jest groźny, kiedy to głosząc swoje twierdzenia i prawa jako jedynie prawdziwe czy jedynie słuszne, najlepsze - często konfrontacyjnie, przeciw innym - uważa, iż nie ma potrzeby dopuszczania do głosu innych szkół naukowych, a jego tezy mają obowiązywać wszystkich, bez względu na ich akceptację. Odbiera tym samym prawo do ich własnych generalizacji wiedzy czy teorii, nie dopuszcza nowych perspektyw badawczych, a tym samym hamuje rozwój nauki. (Śliwerski, 2007: 448)

Kolejnym ważnym problemem są przesunięcia, przemieszczenia paradygmatyczne, miksowanie paradygmatów i tworzenie wewnętrznie sprzecznych hybryd. Badania Doroty Klus-Stańskiej (2010) pokazały, iż w obszarze teorii i praktyki dydaktycznej mamy do czynienia z szeregiem różnego rodzaju deformacji paradygmatycznych, splątań teoretycznych oraz wyprowadzanych aplikacji praktycznych. Kategorią użyteczną dla opisu rzeczywistości dydaktycznej stał się dla autorki „chaos” i jednostka chorobowa zwana „tańcem św. Wita”. D. Klus-Stańska przeprowadzała badania w szkole na poziomie edukacji wczesnoszkolnej i podstawowej. Czy przeprowadzenie analogicznych badań w uniwersytetach i szkołach wyższych doprowadziłoby do analogicznych konstatacji? Za wcześnie o tym wyrokować. Pojawiają się jednak już pewne przesłanki, które zdają się potwierdzać wspomnianą analogię. Prowadząc aktywną działalność na rzecz budowania i doskonalenia kompetencji dydaktycznych doktorantów i nauczycieli akademickich w Uniwersytecie Jagiellońskim, w latach 2012-2015 zgromadziłam 248 esejów pisanych przez uczestników różnorodnych kursów podnoszących ich wiedzę i umiejętności z zakresu dydaktyki akademickiej na temat: „Oceń przydatność wybranej strategii motywowania studentów do uczenia się we własnym warsztacie dydaktycznym”. Warto nadmienić, że grupa była bardzo zróżnicowana i autorami esejów są zarówno osoby związane z biotechnologią, matematyką, medycyną, jak i filozofią, historią sztuki czy filologiami. Ponadto przeprowadziłam 43 obserwacje zajęć ze studentami (tym razem jedynie na zajęciach z pedagogiki), które poddałam starannej analizie od strony dydaktycznej oraz rozpoznawania oznak tego, co D. Klus-Stańska nazywa „uczeniem się po śladzie”. To jedynie badania wstępne, eksplorujące teren badawczy, ale analiza tak drobnej próbki badawczej już pozwala podzielić się pewnymi konstatacjami:

- Praktycznie nieobecne (lub śladowe) wśród doktorantów i nauczycieli akademickich jest podejście, które lokowałoby się w paradygmacie humanistycznym. Z analizy esejów wynika, iż znacząca część osób postrzega ten paradygmat jako utopijny, nierealistyczny, niezgodny $z$ wymaganiami uniwersytetu. Dopuszcza wprawdzie istnienie tak zwanych dobrych praktyk 
$\mathrm{w}$ postaci tutoringu akademickiego, ale też tylko w formie tutoringu naukowego, a nie rozwojowego. Pojawiają się za to stwierdzenia typu: „ja nie jestem od tego, aby studentowi było miło”, „przy takiej ilości studentów nie ma możliwości jakiejkolwiek indywidualizacji”, „atmosfera bezpieczeństwa i zaufania to na terapii, a nie na zajęciach”. Paradygmat humanistyczny jawi się nauczycielom akademickim jako „kwiatek do kożucha”.

- Paradygmat konstruktywistyczny w postaci różnych postulatów dotyczących procesu nauczania-uczenia się jest obecny przede wszystkim we wszystkich zapisach i dokumentach dotyczących jakości kształcenia. Sami nauczyciele akademiccy utożsamiają go najczęściej z metodami i formami pracy, w tym przede wszystkim z metodami aktywizującymi oraz pracą grupową, jednak na zajęciach nie pozostawiają studentom wystarczającej ilości czasu na poszukanie, wytworzenia rozwiązania i wkraczają w tok pracy ze swoją interwencją dydaktyczną. Preferują przy tym wytwory, pomysły i prace studenckie, które wpisują się w ich tok myślenia i podawane przez nich ścieżki rozwiązań. Nie widzą też najczęściej związku pomiędzy umożliwianiem studentom eksplorowania różnych dróg kształcenia a sposobem oceny wykonanych przez nich prac. Kontrola i ocena mają najczęściej funkcję rozliczającą, a nie diagnostyczną, wspierającą czy motywacyjną.

- Pomimo różnego typu szkoleń na rzecz promowania dydaktyki konstruktywistycznej wciąż najmocniej obecny jest paradygmat behawiorystyczny z typowym uczeniem po śladzie. Warto także zwrócić uwagę na najczęściej wymieniane w esejach narzędzia motywowania studenta, które nauczyciele i doktoranci polecają. Należą do nich:

- pełna kontrola nauczyciela nad wszystkimi elementami procesu kształcenia, niemal zerowy obszar wolności studenta („muszę wiedzieć, co student robi i kiedy"),

- stałe monitorowanie i rozliczanie pracy studenta na przykład w postaci list obecności, odnotowywania wszelkich aktywności i jej braku oraz częstych kolokwiów - „wejściówek” lub „wyjściówek” („muszę przecież studenta sprawdzić”),

- nagrody w postaci dodatkowych punktów podwyższających ocenę końcową („to ich skłania do czytania tekstów i udzielania się na zajęciach”),

- kary za błędne wykonanie lub brak aktywności w postaci punktów ujemnych prowadzących do obniżenia oceny, czasem nawet obniżenia oceny z egzaminu końcowego („to ich jeszcze bardziej motywuje do uczenia się"),

- wprowadzanie mechanizmów rywalizacyjnych najczęściej w postaci konkursów typu „zwycięzca (lub trzech najlepszych) bierze wszystko”. 
Czy jednak mamy dążyć do tego, by promując na przykład konstruktywizm, wyeliminować wszelkie formy „behawioralnego sterowania”? Moim zdaniem zdecydowanie nie. Podejście behawiorystyczne ma głęboki sens, ale ten sens zależy od tego, jakiego rodzaju efekty kształcenia chcemy osiągnąć.

\section{W obronie komplementarności podejść}

Stosunkowo łatwo jest ulec pokusie i promować tylko jeden paradygmat - konstruktywistyczny, który jako najbardziej zróżnicowany i pojemny mieści w sobie zarówno uzasadnienia neurobiologiczne ludzkiego myślenia, jak i wątki interpretacyjne, społeczno-kulturowe (Sajdak, 2013: 387 i następne). W najszerszym swym nurcie konstruktywizm przybiera postać odwołującą się do prac Jeana Piageta oraz Jerome’a S. Brunera. W literaturze pedagogicznej z kręgu niemieckiego i anglojęzycznego widać wyraźny prymat tego podejścia. W odniesieniu do dydaktyki szkolnej można mówić nawet - jak podkreśla Bogusława Dorota Gołębniak - „o nowej modzie czy nawet religii edukacyjnej” (Gołębniak, 2002: 20). W dydaktyce akademickiej paradygmat ten bynajmniej nie jest religią, jest natomiast mocno promowany i widoczny w zapisach dotyczących jakości procesu kształcenia. W praktyce kształcenia studentów znajduje on zastosowanie przede wszystkim poprzez wykorzystywanie metod problemowych, aktywizujących oraz różnorodnych form pracy grupowej. Niezależnie od faktu, czy w istocie kształcenie studentów wykorzystuje ścieżki podpowiadane przez konstruktywizm psychologiczny lub społeczno-kulturowy, czy ów konstruktywizm pozostaje głównie na poziomie życzeń i deklaracji, niemal wszyscy są zgodni, iż stanowi on rdzeń pożądanej, nowoczesnej dydaktyki akademickiej. Nie trzeba zatem stawać w jego obronie. Moim zdaniem należy raczej dostarczyć argumentów za zasadnością ścieżek wywiedzionych z paradygmatu humanistycznego i behawiorystycznego.

Uważam, iż argumentów za uznaniem zasadności i komplementarności różnych podejść do procesu kształcenia wywiedzionych z różnych podejść paradygmatycznych dostarcza analiza efektów kształcenia. Wraz z wprowadzeniem Krajowych Ram Kwalifikacji zmieniliśmy opis celów akademickiego kształcenia, które od tamtej pory opisujemy językiem efektów kształcenia, układając je w trzy kategorie: wiedzy, umiejętności (mentalnych i/lub praktycznych) oraz kompetencji społecznych. Zależność pomiędzy efektami kształcenia a możliwymi drogami do nich prowadzącymi, czyli strategiami kształcenia, przedstawia poniższy schemat: 


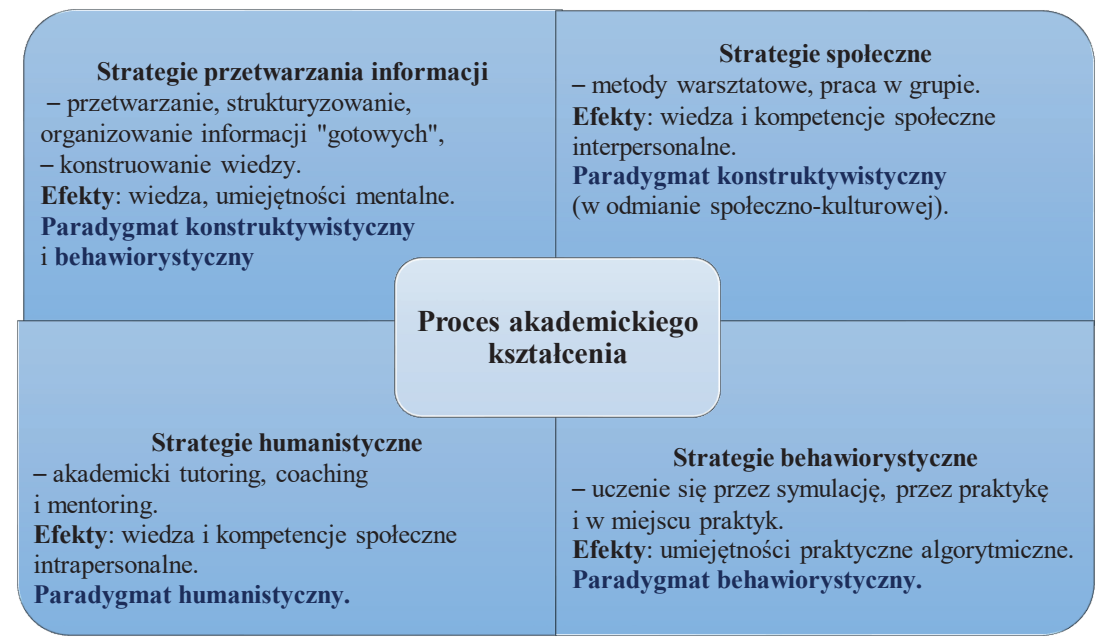

Ryc. 1. Strategie kształcenia a efekty kształcenia

Źródło: opracowanie własne

Typologia strategii kształcenia przyjęta została pośrednio za Bogusławą Dorotą Gołębniak, która głównym kryterium doboru uczyniła rozpoznane we współczesnej psychologii następujące wzory uczenia się (Gołębniak, 2007: 172-173):

- pod wpływem wzmocnień zewnętrznych, uzyskiwanych informacji zwrotnych (strategie behawiorystyczne);

- aktywne przyswajanie, przetwarzanie i produkowanie informacji (strategie przetwarzania informacji);

- oparte na wzorach społecznego uczenia się (strategie społeczne);

- całościowe, osobowościowe (strategie humanistyczne).

Propozycja Bogusławy Doroty Gołębniak bezpośrednio nawiązuje do prac Bruce’a Joyce’a, Emily Calhoun oraz Davida Hopkinsa (1999), którzy to wskazali cztery grupy modeli nauczania - przetwarzania informacji, społeczne, behawioralne i rozwoju osobowości. Autorka rezygnuje jednak z używania kategorii „model" jako wywodzącej się z behawioralnego, tradycyjnego myślenia o edukacji. Uważam, że, nie wdając się w niepotrzebne spory co do definiowania kategorii model, strategia, metoda czy technika kształcenia, można z powodzeniem przyjąć kategorię „strategia” jako szerokiej, obejmującej całe zespoły zaplanowanych czynności nauczyciela oraz uczącej się osoby. W tym też względzie chciałabym wskazać zasadność i konieczność wykorzystywania wszystkich strategii kształcenia prowadzących do różnych, a pożądanych przez nas efektów. Proces studiowania, niezależnie od kierunku kształcenia, zawsze opiera się na zdobywaniu przez studenta wiedzy ze wskazanego obszaru oraz kształtowaniu szeregu umiejętności 
kognitywnych. W tym celu proponujemy studentom udział w wykładach, ćwiczeniach, konwersatoriach, lektoriach, laboratoriach, warsztatach i innego typu klasycznych formach zajęć. Spór o kształt procesu kształcenia może toczyć się wokół pytania: czy kształcenie ma mieć bardziej charakter transmisyjny w postaci podawania studentowi gotowej do przyswojenia wiedzy, czy też studiowanie ma być dla osoby uczącej się swego rodzaju „siłownią umysłową"? Może, ale nie musi. Wszak niższe poziomy taksonomiczne efektów kształcenia wskazują dokładnie, jaką wiedzę student ma przyswoić, nauczyć się niemal „na pamięć”. W każdym obszarze kształcenia możemy wskazać całe pokłady wiedzy w miarę pewnej, kanonicznej, której opanowanie stanowi podstawę do dalszego studiowania i możliwego stawiania pytań o prawomocność tej wiedzy. Często także jej opanowanie jest wręcz warunkiem dalszego studiowania. W celu osiągnięcia tak zdefiniowanych efektów stosujemy w toku procesu kształcenia najczęściej wykład i pracę z tekstem, które to metody pomagają studentowi gromadzić, przetwarzać, strukturyzować i zapamiętać informacje gotowe. I wtedy transmisyjne oraz selekcyjne działania wywiedzione z paradygmatu behawiorystycznego mogą być przydatne. Osiąganie efektów kształcenia wpisujących się w wyższe poziomy taksonomiczne (np. w taksonomii poznawczej Benjamina Blooma) za pomocą wykładu wydaje się już niemal niemożliwe. Dlatego też najczęściej sięgamy do działań uprawomocnionych przez paradygmat konstruktywistyczny i metod wspierających samodzielne konstruowanie przez studenta wiedzy. Do najbardziej znanych należą: Problem Based Learning (PBL) - nauczanie oparte na rozwiązywaniu problemu, metoda projektu, metoda przypadku, metody aktywizujące z technikami w postaci: gier dydaktycznych, rybiego szkieletu, analizy SWOT, drzewka decyzyjnego, metaplanu i innych. Proces studiowania ma doprowadzić studenta nie tylko do osiągnięcia założonych efektów opisanych w postaci wiedzy i umiejętności, ale także wspierać rozwój kompetencji społecznych. Analizując zapisy w programach kształcenia, można wyróżnić co najmniej dwie kategorie kompetencji społecznych, które odnoszą się do sfery interpersonalnej oraz intrapersonalnej. Do tej pierwszej zaliczyłabym wskazania odnoszące się do umiejętności związanych z komunikacją interpersonalną („student posiada umiejętność dyskutowania, uczestniczenia w debacie, prezentowania wyników, wiedzy, opinii, stanowisk, posiada gotowość do dzielenia się doświadczeniami”) oraz do umiejętności pracy w grupie i z grupą („student potrafi pracować indywidualnie i w zespole, planować pracę własną i zespołową, posiada gotowość do współdziałania”). Jak osiągnąć tak zaplanowane efekty kształcenia? Na przykład poprzez korzystanie ze ścieżek podpowiadanych przez strategie społeczne w postaci warsztatów pracy w grupie, Team Based Learning, dramę, modele badania wartości, debatę oksfordzką, dyskusję sokratejską i innych, 
ukierunkowanych na wykorzystywanie społecznych wzorów uczenia się, a wypracowanych w obszarze paradygmatu konstruktywistyczno-społecznego (społeczno-kulturowego). Drugi rodzaj formułowania efektów w kategorii kompetencje społeczne odnosi się do kompetencji intrapersonalnych, a znajduje swój wyraz w opisach kompetencji ukierunkowanych na rozwój własny, na stałe uczenie się, na podnoszenie swych kompetencji profesjonalnych („student potrafi planować własne uczenie się, rozwój zawodowy, posiada gotowość do przejęcia odpowiedzialności za własne przygotowanie zawodowe, posiada nastawienie na rozwój zawodowy i stałe podnoszenie swych kwalifikacji”). Jak osiągnąć tak sformułowane efekty kształcenia? Moim zdaniem na drodze stosowania strategii lub elementów strategii humanistycznych, wspierających rozwój osobowy osoby uczącej się i jej nastawienie na rozwój zawodowy. Tu pomocny jest tutoring akademicki w różnych odmianach i wymiarach. Wiele kierunków kształcenia zakłada także nabycie przez studentów określonych umiejętności praktycznych, w tym algorytmicznych. Idealnym rozwiązaniem jest stosowanie metod kształcenia opartych na uczeniu się przez symulację, w laboratorium, przez praktykę i w miejscu praktyk. I tu pomocny jest paradygmat behawiorystyczny w nowoczesnym wydaniu. U podstaw konstruowania strategii kształcenia leży założenie, iż człowiek stanowi samokorygujący się system komunikowania. Dzięki otrzymywanym w trakcie wykonywania danego zadania informacjom zwrotnym dotyczącym zgodności z prezentowanym uprzednio wzorem danej czynności może korygować swoje zachowania aż do stanu uznawanego standardu. Zatem nawet tak krytykowane podejście tradycyjne, oparte na behawioralnym sterowaniu, ma moim zdaniem głęboki sens pod warunkiem, iż popatrzymy na całość różnych ścieżek nauczania - uczenia się oraz zrezygnujemy z pierwotnego skinnerowskiego rozumienia behawioryzmu.

\section{Literatura}

Barr R.B., Tagg J. (2000). From teaching to learning. A new paradigm for undergraduate education. [W:] D. DeZure (ed.). Learning from Change. Landmarks in Teaching and Learning in Higher Education from Change Magazine 1969-1999, London, s. 198-200.

Bauman T. (2006). Dydaktyka szkoły wyższej - ujęcie dyscyplinarne. [W:] A. Szerląg (red.). Problemy edukacji w szkole wyższej. Kraków.

Brown G., Atkins M. (1988). Effective Teaching in Higher Education. New York.

Gołębniak B.D. (2002). Nabywanie kompetencji do refleksyjnego nauczania. [W:] B.D. Gołębniak (red.). Uczenie się metoda projektów. Warszawa.

Gołębniak B.D. (2007). Nauczanie i uczenie się w klasie. [W:] Z. Kwieciński, B. Śliwerski (red.). Pedagogika. Podręcznik akademicki. T. 2. Warszawa.

Hessen S. (1997 [1923¹]). Podstawy pedagogiki. Warszawa. 
Joyce B., Calhoun E., Hopkins D. (1999). Przykłady modeli uczenia się i nauczania. Warszawa.

Klus-Stańska D. (2002). Konstruowanie wiedzy w szkole. Olsztyn.

Klus-Stańska D. (2009). Polska rzeczywistość dydaktyczna - paradygmatyczny taniec św. Wita. [W:]

L. Hurło, D. Klus-Stańska, M. Łojko (red.). Paradygmaty współczesnej dydaktyki. Kraków.

Klus-Stańska D. (2010). Dydaktyka wobec chaosu pojęć i zdarzeń. Warszawa.

Krause A. (2010). Wspótczesne paradygmaty pedagogiki specjalnej. Kraków.

Kuhn T.S. (2001). Struktura rewolucji naukowych, przeł. H. Ostromęcka, J. Nowotniak. Warszawa.

Malewski M. (2010). Od nauczania do uczenia się. O paradygmatycznej zmianie $w$ andragogice. Wrocław.

Okoń W. (1993). Dydaktyka szkoły wyższej. [W:] W. Pomykało (red.). Encyklopedia pedagogiczna. Warszawa.

Palka S. (2004). Aktualne tendencje w dydaktyce akademickiej. [W:] D. Skulicz (red.). W poszukiwaniu modelu dydaktyki akademickiej. Kraków, s. 31-36.

Sajdak A. (2013). Paradygmaty kształcenia studentów i wspierania rozwoju nauczycieli akademickich. Teoretyczne podstawy dydaktyki akademickiej. Kraków.

Sajdak A. (2016). Interdyscyplinarność dydaktyki akademickiej. „Rocznik Komisji Nauk Pedagogicznych" nr LXIX, s. 5-16.

Suska-Wróbel R. (2009). Od potoczności do nauki - próba identyfikacji samoświadomości dydaktyków biologii. [W:] L. Hurło, D. Klus-Stańska, M. Łojko (red.). Paradygmaty współczesnej dydaktyki. Kraków, s. 190-200.

Śliwerski B. (2007). Jaki paradygmat?. [W:] J. Rutkowiak, D. Kubinowski, M. Nowak (red.). Edukacja, moralność - sfera publiczna. Lublin. 